\title{
Postnational discourse, deliberation, and participation toward global risk governance
}

\author{
ANDREAS KLINKE*
}

\begin{abstract}
An emerging task in world politics is to cope with human-induced global risks in domains such as environment, economy, security, and health. Current global governance institutions are largely incapable of tackling global risks and applying deductive policy models, which is why new modes of interaction may become essential. In this article I argue that through focused discourses, key peculiarities of global risks, namely complexity, scientific uncertainty and sociopolitical ambiguity, may be identified and understood. To this end, distinctively discursive and pragmatic learning processes can be developed. Different forms of deliberation and participation help develop processes that meet the challenges, problems, and conflicts that result from the key peculiarities of global risks. Hence, the article establishes a causal link between key peculiarities of global risks and postnational discourses. I discuss the varying forms of deliberation and participation (epistemic institutions, associational policy making, and transnational public deliberation and participation) of three discourses that produce institutional problem solving capacity in global risk governance. To this end, this article links theory and practice as well as normative conceptualisation and institutional feasibility.
\end{abstract}

Dr Andreas Klinke is Associate Professor at the Department of Political Science and the Environmental Policy Institute at Memorial University of Newfoundland, Canada. Prior to that, he was Head of a Research Group at the Swiss Federal Institute of Aquatic Science and Technology and Lecturer at King's College London. His research and teaching activities include environmental policy, risk governance, international environmental politics, global governance, deliberation, and participation.

Contemporary modern societies are increasingly confronted with the task in world politics of coping with human-induced, globally relevant risks that threaten sociopolitical and economic systems throughout the world. To address the scopes and impacts of these global risks, which often transcend political units, societal realms, and natural systems, global risk governance institutions and public policy beyond the state need to break new ground. ${ }^{1}$ However, current global governance structures seem to be largely lacking the institutional and procedural capacity to deal with these

* For comments on earlier drafts I am grateful to Philip Genschel, Michael Zürn, and the participants of the international workshop 'Institutional dynamics in world politics: explaining variation in the scope, pace, and direction of international institutional change' at the Social Science Research Center, Berlin, Germany in April 2011. My thanks also go to the three anonymous reviewers for their helpful comments.

1 Governance has been defined both broadly and narrowly. I refer to the broad understanding meaning 'the processes and institutions, both formal and informal that guide and restrain the collective activities of a group', see Robert O. Keohane and Joseph S. Nye, 'Introduction', in Joseph S. Nye and John D. Donahue (eds), Governance in a Globalizing World (Washington: Brookings Institutions, 2000), p. 12. 
global risks effectively, which is why new modes of interaction have become essential in global risk governance. ${ }^{2}$ The central argument of this article is that institutional arrangements of global risk governance require a discursive turn in order to tackle key peculiarities of global risks, namely complexity, scientific uncertainty, and sociopolitical ambiguity and the resulting challenges, problems, and conflicts. This presupposes the emergence of transnational public spheres in which a new interplay between the state, economy, and civil society is possible and in which deliberative and participatory transnational procedures of global governance institutions aggregate postnational discourses in the formation of public opinion and will.

Some scholars see global risks as emerging in a broad array of political science domains such as environment, economy, security, and health that undermine and burden world politics and pose a major challenge to the institutional requisites and coping mechanisms of global governance. ${ }^{3}$ These risks may be associated with new modern technologies such as bioengineering, man-made global warming, the loss of biosphere functions, cumulative effects relating to environmental hazards, the depletion of natural resources, the occurrence of new pandemics (such as HIV, SARS, or avian flu), new forms of terrorism, and financial and economic crises.

Global governance institutions appear to be mostly incapable of applying deductive policy models in addressing such global risks. In this article, I explore how the institutional and procedural incapability of global governance can be overcome through distinctively discursive and pragmatic learning processes. The underlying assumption is that key peculiarities of global risks, which can be identified, understood, classified, and systematised, provide a heuristic tool. This tool enables the deducing and distinguishing of challenges, problems, and conflicts that result from the peculiarities, and in this article I develop distinctively discursive and pragmatic policy models to address these challenges. The discursive policy models are based on deliberative and participatory problem solving capacities. They develop a solid understanding and learning of the challenges, problems, and conflicts arising from global risk peculiarities that cannot be tackled without discursive and deliberative coordination and cooperation aimed at collective problem solving.

Methodologically speaking, the article establishes a causal link between key peculiarities of global risks and postnational discourses. I argue that postnational discourses that are conveyed and aggregated by varying forms of transnational deliberation and participation can produce institutional problem solving capacity in

2 Scholarly ideas on such new global governance structures are manifold, see, for example, Ulrich Beck, 'World Risk Society and the Changing Foundations of Transnational Politics', in Edgar Grande and Louis W. Pauly (eds), Complex Sovereignty: Reconstituting Political Authority in the 21st Century (Toronto: University of Toronto Press, 2005), pp. 22-47; Ulrich Beck, World at Risk (Cambridge: Polity Press, 2009); Frank Biermann, Philipp Pattberg, Harro van Asselt, and Fariborz Zelli, 'The Fragmentation of Global Governance Architectures: A Framework for Analysis', Global Environmental Politics, 9:4 (2009), pp. 14-40; Frank Biermann et al., 'Navigating the Anthropocene: Improving Earth System Governance', Science, 335 (16 March 2012), pp. 1306-7; Edgar Grande and Bernhard Zangl, 'Varieties of Preventive Governance in World Risk Society', Paper presented at the Annual Convention of the International Studies Association, Montréal, 15-19 March 2011); Peter M. Haas, 'Addressing the Global Governance Deficit', Global Environmental Politics, 4:4 (2004), pp. 1-15.

3 See also Ulrich Beck, World Risk Society (Cambridge: Polity Press, 1999); Beck, World at Risk; Ulrich Beck and Edgar Grande, Cosmopolitan Europe (Cambridge: Polity Press, 2007); Grande and Zangl, 'Varieties of Preventive Governance in World Risk Society'; Elke Krahmann, 'Beck and Beyond: Selling Security in the World Risk Society', Review of International Studies, 37:1 (2011), pp. 349-72; Barak Mendelsohn, 'Sovereignty Under Attack: The International Society Meets the Al Qaeda Network', Review of International Studies, 31:1 (2005), pp. 45-68. 
global risk governance and thus serve as the dependent variable. Postnational discourses epitomise a dynamic configuration in the context of global governance that enables the permeation of the opacity of global risk phenomena and related issues. The manifestation of postnational discourses through deliberative and participatory transnational processes offers ways to proceed to the very heart of the challenges, problems, and conflicts associated and provides superior outcomes in terms of potential problem solving. To this end, the article links theory and practice as well as normative conceptualisation and institutional feasibility.

Scholars of discursive and deliberative democracy theories view the development of problem solving as a rational discourse resulting in norms and rules assuming a presumptive causal link. ${ }^{4}$ Discourses are expected to facilitate the logic of action through which actors can understand and learn about the interests of others. Actors may change their beliefs and preference systems and aim at a consensus deemed socially and publicly acceptable by means of deliberation, arguing, and persuasion. Discourses demand high normative claims: actors are supposed to share common reference frames and meaning structures; inclusiveness, equal communication rights, truthfulness, reference to the common good, and the public use of reason should be ensured; manipulation, asymmetric power relations, and repression should be excluded. Rational discourse and public deliberation are based on an ideal democratic view that may not empirically occur in a pure form in world politics and may not be as coherent and logical as the normative viewpoint of the theories aver. Hence the question arises as to how a normative approximation of postnational discourses that are conveyed by transnational deliberation and participation in order to produce institutional problem solving capacity in global governance would look like that is pragmatic and feasible.

While taking into account the conditions of rational discourse, deliberative democracy, and communicative action in International Relations - which have recently been addressed in political science literature ${ }^{5}$ - I substantiate that different peculiarities of global risks imply varying discourses with different focal points and purposes.

4 James Bohman, Public Deliberation. Pluralism, Complexity, and Democracy (Cambridge: MIT Press, 1996); John Dryzek, Discursive Democracy (Cambridge: Cambridge University Press, 1990); Jon Elster, 'Deliberation and Constitution Making', in Jon Elster (ed.), Deliberative Democracy (Cambridge: Cambridge University Press, 1998); Jürgen Habermas, Between Facts and Norms: Contributions to a Discourse Theory (London: Polity, 1996); Maarten Hajer, The Politics of Environmental Discourse. Ecological Modernization and the Policy Process (Oxford: Clarendon Press, 1995).

${ }^{5}$ Mathias Albert, Oliver Kessler, and Stephan Stetter, 'On Order and Conflict: International Relations and the "Communicative Turn", Review of International Studies, 34 (2008), pp. 43-67; Walter E. Baber and Robert F. Bartlett, Global Democracy and Sustainable Jurisprudence: Deliberative Environmental Law (Cambridge: MIT Press, 2009); Nicole Deitelhoff, 'The Discursive Process of Legalization: Charting Islands of Persuasion in the ICC Case', International Organization, 63:1 (2009), pp. 33-65; Christian Grobe, 'The Power of Words: Argumentative Persuasion in International Negotiations', European Journal of International Relations, 16:1 (2010), pp. 5-29; Andreas Klinke, 'Democratizing Regional Environmental Governance: Public Deliberation and Participation in Transboundary EcoRegions', Global Environmental Politics, 12:3 (2012), pp. 79-99; Andreas Klinke, 'Deliberative Politik in transnationalen Räumen - demokratische Legitimation und Effektivität der grenzüberschreitenden Wasser- und Umweltpolitik zwischen Kanada und USA', Politische Vierteljahresschrift, 50:4 (2009), pp. 774-803; Andreas Klinke, 'Deliberative Transnationalism - Transnational Governance, Public Participation and Expert Deliberation', Forest Policy and Economics, 11 (2009), pp. 348-56; Thomas Risse, 'Global Governance and Communicative Action', Government and Opposition, 39 (2004), pp. 288313; Thomas Risse, “Let's Argue!”: Communicative Action in World Politics', International Organization, 54:1 (2000), pp. 1-39; Jens Steffek, 'The Legitimation of International Governance: A Discourse Approach', European Journal of International Relations, 9:2 (2003), pp. 249-75. 
The varying discourse foci can be seen as distinctive, yet they are intertwined, interacting and complementary as well; they adopt different means of solidifying postnational discourses through deliberation and participation and adjust to the specificity of the key peculiarities of global risks.

The key peculiarities of global risks - complexity, scientific uncertainty, and sociopolitical ambiguity - are seen as generic features. Complexity refers to the difficulty of assessing causal and temporal relationships. Scientific uncertainty refers to variation among target areas, measurement and inferential errors, genuine stochastic relationships, system boundaries, and lack of knowledge. Finally, sociopolitical ambiguity refers to different interpretations of data and their results. The manifestation of these peculiarities is sometimes immediate and obvious but more often subtle and lagged. They delineate the absence of knowledge in a sociological sense and construe knowledge as an expectation that is socially constructed and attributed, and they refer to the insufficiency of truth in the cognitive sense common in philosophy and in the theory of science. Moreover, there is a lack of a broader societal and political consensus of how to handle this kind of insecurity. ${ }^{6}$ Thus the peculiarities relate to the state of bounded rationality, the availability and quality of reliable and consolidated knowledge as well as basic understandings in terms of shared beliefs, moral judgments, and broader worldviews. The peculiarities bring characteristic challenges, problems, and conflicts out of the shadow of obscurity and nescience into a realm where the issues can be targeted by different forms of deliberation and participation.

There has not yet been a sufficient inquiry into the role of postnational discourses focusing on global risks in the literature. In addressing this lack, the article's primary intent is to conceptualise a normative, pragmatic, and feasible approximation of postnational discourses, which are conveyed by transnational deliberation and participation creating institutional problem solving capacity that would strengthen global risk governance. It aims to contribute to the contemporary debate of the possibility of controlling global risks in world politics and the new nature of political authority shared by public and private actors in global governance. In order to accomplish this, I attempt to unravel the phenomenological couplings of global risks by distinguishing between complexity, scientific uncertainty, and sociopolitical ambiguity, because the resulting challenges, problems, and conflicts require different discourse foci and different forms of deliberation and participation. Deliberative and participatory institutional capacity generates an epistemic value by facilitating a discursive 'give and take of reasons'. ${ }^{7}$ This dialogical character enhances the quality of justification toward a good decision that could qualify the authority and legitimacy of global risk governance institutions. ${ }^{8}$ If processes rely on relevant systematic knowledge, argumentative rationality with regard to elements of knowledge and ethical norms, diverse forms of transnational deliberation and participation at various levels of organisation as well as openness to the outcome, then such postnational discursive capacity is promising. ${ }^{9}$ Hence the question can be raised: what kinds of postnational

${ }^{6}$ Cf. Beck, World at Risk; Jürgen Habermas, The Theory of Communicative Action: Reason and the Rationalization of Society (London: Heinemann Education, 1984).

7 Bohman, Public Deliberation, p. 32.

${ }^{8}$ Cf. David Estlund, Democratic Authority: A Philosophical Framework (Princeton: Princeton University Press, 2009).

9 Cf. James Bohman, Democracy across Borders. From Dêmos to Dêmoi (Cambridge: MIT Press, 2007); James Bohman, 'Epistemic Value and Deliberative Democracy', The Good Society, 18:2 (2009), pp. 2834. 
discourse foci can be deduced from key peculiarities of global risks and how would the respective variation of institutional problem solving capacity through transnational deliberation and participation be shaped?

To answer this question, I propose three distinctive postnational discourse foci for global risk governance that are interconnected and complementary. The distinction thereby benefits from the diversity of deliberative and participatory forms. These discursive approaches address specific challenges, problems, and conflicts resulting from complexity, uncertainty, and ambiguity, respectively. In so doing, I critically reflect on their feasibility and applicability in transboundary and international contexts.

For the purpose of the conceptualisation of a normative approximation toward postnational discourses as institutional problem solving means, I adopt a discourseoriented perspective on global governance following along the lines of discursive institutionalism. Discursive institutionalism has recently been added to the three 'older' new institutionalism approaches of rational choice, historical, and sociological institutionalism. ${ }^{10}$ Discursive institutionalism is increasingly gaining ground in International Relations. It underscores the thesis expanded on in this article that international institutions can frame discourses between political and societal actors as interactive and communicative processes developing and fostering substantive content on how to overcome obstacles and to solve problems of knowledge-related insecurity. Discursive institutionalism is a dynamic and functional approach to global risk governance that can shed light on particular aspects of discursive, deliberative, and participatory settings in institutional contexts that provide structures and resources for solving problems related to global risks. This approach provides a logic of discursive rationality that differs significantly from the logic of instrumental rationality theorised by proponents of rational choice institutionalism, the path dependency of historical institutionalism, and the 'logic of appropriateness' found in sociological institutionalism. ${ }^{11}$ The basic assumptions underlying the older new institutionalisms represent a more equilibrium-focused and static view that is challenged by the 'new' discursive institutionalism, which has a more dynamic take on change and discourse as explanatory variables.

The article firstly differentiates and systematises key peculiarities of global risks and the resulting challenges, problems, and conflicts in order to identify postnational discourses of deliberation and participation that are able to address these peculiarities. I then review and reconstruct the idea of a transnational public sphere as a societal medium and 'hotbed' enabling the formation of public opinion and will across national borders. This is the keystone on which a transnational public community can be built and that constitutes the requisite for the evolution of postnational discourses that are conveyed by transnational deliberation and participation. Thereafter, I advance the normative approximation and categorisation of three discourse foci that institutionalise the concentration of postnational discourses

10 Vivien A. Schmidt, 'Discursive Institutionalism: The Explanatory Power of Ideas and Discourse', Annual Review of Political Science, 11 (2008), pp. 303-26. A similar approach has been denoted as constructivist institutionalism, see Colin Hay, 'Constructivist Institutionalism', in R.A.W. Rhodes, Sarah A. Binder, and Bert A. Rockman (eds), The Oxford Handbook of Political Institutions (Oxford: Oxford University Press, 2006), pp. 56-74.

11 Peter A. Hall and Rosemary C. R. Taylor, 'Political Science and the Three New Institutionalisms', Political Studies, 154:5 (1996), pp. 936-57; James G. March and Johan P. Olsen, 'Elaborating the "New Institutionalism",, in R.A.W. Rhodes, Sarah A. Binder, and Bert A. Rockman (eds), The Oxford Handbook of Political Institutions (Oxford: Oxford University Press, 2006), pp. 3-20. 
through transnational deliberation and participation by means of epistemic institutions, associational policymaking and transnational general public deliberation and participation. Examples such as the Intergovernmental Panel on Climate Change (IPCC), the Forest Stewardship Council (FSC), and the North American Great Lakes regime serve as illustrations for making the theoretical conceptualisation of discursive, deliberative, and participatory governance approaches and their rationales more tangible. The last section discusses the implications of and conclusions about global governance structures.

\section{Key peculiarities of global risks}

The handling and control of the key peculiarities of global risks often relate to the functional and structural interdependencies, interactions, and dynamics within and between sociopolitical, economic, and/or ecological systems. By using the terms complexity, scientific uncertainty and sociopolitical ambiguity, I can reasonably identify, classify, and systematise three key peculiarities. ${ }^{12}$ It is a categorisation of generic features of global risks that refers to differing degrees and dimensions of the incompleteness, availability, intersubjective certitude, validity, and explanatory power of knowledge of global risks. This allows me to draw conclusions about the design of global risk governance. The distinction between complexity, scientific uncertainty, and sociopolitical ambiguity is an attempt to understand, order, and feature the associated challenges, problems, and conflicts and link them to collective efforts of what we can do about them in the sense of ordering courses of action in global risk governance. Emerging challenges, problems, and conflicts result from issues of identifying and capturing unclear, elusive and multilayer causalities, the fragmentariness of available knowledge, the lack of valid knowledge, competing knowledge claims, as well as different empirical and normative assertions of validity claims.

While complexity and scientific uncertainty mostly create challenges and problems of intersubjective comprehension and scientific knowledge relating to causal beliefs, sociopolitical ambiguity implies differences and conflicts with respect to preference orders, ethical norms and values embedded in principled beliefs and world views. The distinction and connection between causal and principled beliefs as well as world views, as Judith Goldstein and Robert O. Keohane put it, ${ }^{13}$ may help us to understand the reference frames and meaning structures behind the challenges and problems resulting from complexity, scientific uncertainty, and sociopolitical ambiguity. Causal beliefs refer to the shared consensus of recognised elites, such as scientists, about cause-and-effect relationships. Scientific knowledge addresses the involved cognitive challenges and problems. Principled beliefs relate to ideational norms and rules that guide us in distinguishing between right and wrong and just and unjust. Principled

12 Andreas Klinke and Ortwin Renn, 'A New Approach to Risk Evaluation and Management: RiskBased, Precaution-Based and Discourse-Based Strategies', Risk Analysis, 22:6 (2002), pp. 1071-94; Andreas Klinke and Ortwin Renn, 'Adaptive and Integrative Governance on Risk and Uncertainty', Journal of Risk Research, 15:3 (2012), pp. 273-92.

13 Judith Goldstein and Robert O. Keohane, 'Ideas and Foreign Policy. An Analytical Framework', in Judith Goldstein and Robert O. Keohane (eds), Ideas and Foreign Policy. Beliefs, Institutions, and Political Change (Ithaca: Cornell University Press, 1993), pp. 8-11. 
beliefs are embedded in the third type of reference frame, namely worldviews. Worldviews are larger belief systems that encompass even antagonistic principled beliefs. Worldviews are based on religiously and socio-culturally determined conceptions and value systems including views about ontology and ethics. These types of beliefs are not detached but rather interdependent: 'Causal beliefs imply strategies for the attainment of goals, themselves valued because of shared principled beliefs, and understandable only within the context of broader world views.' ${ }^{14}$ Correspondingly, the challenges and problems of complexity, uncertainty, and ambiguity are distinguishable, but they need also to be seen as intertwined when designing institutional capacity to tackle them.

\section{Complexity}

Complexity refers to a multifaceted web of causal relationships, where many intervening factors affect the outcome of an event or activity so that the identification and mapping of correlations between cause and effects are highly complicated. ${ }^{15}$ In many cases, significant spatial and temporal distances between the primary trigger and the impact characterise global risks. The nature of this difficulty can be traced back to interactive effects such as synergism and antagonisms, long delay periods between cause and effect, non-linear response functions, variations regarding different actors and groups, and other intervening variables.

Climate change is a global risk with a high degree of complexity as well as scientific uncertainty and sociopolitical ambiguity. ${ }^{16}$ During the last two decades scientific investigations and modelling have increasingly demonstrated that multiple factors such as global emissions of $\mathrm{CO}_{2}$ and methane cause a human-induced climate change. Some of its effects are global warming, the decline of glaciers, and an augmentation of extreme weather events. This causal relationship together with scientific uncertainty means that whether or not governments prioritise action on prevention, adaptation, and/or mitigation is simultaneously a question of interpretation, values, and justification, and thereby an issue of sociopolitical ambiguity as well.

Since the cause-and-effect relationship is neither obvious nor directly observable, it is precisely these complexities that make sophisticated scientific investigations necessary. Complexity therefore requires sensitivity to non-linear transitions as well as to scalar dimensions at different levels. It also needs to take into account a multitude of pathways and the composite effects of other factors and mechanisms that are present in specific situations.

Furthermore, complexity refers to interdependencies between social, environmental, and/or technological systems. The interrelations are multilayered, extremely difficult, and the knowledge about them is markedly unreliable. The bias of perceptions, social amplifications, cultural contexts, influencing organisational factors, and

14 Ibid., p. 10.

15 Cf. Roger Lewin, Complexity: Life at the Edge of Chaos (New York: Macmillan, 1992); Arild Underdal, 'Complexity and Challenges of Long-Term Environmental Governance', Global Environmental Change, 20 (2009), pp. 386-93.

16 Intergovernmental Panel on Climate Change, 'Climate Change 2007. Synthesis Report of the IPCC Fourth Assessment Report' (Cambridge: Cambridge University Press, 2007). 
time lags regarding the recognition of impacts are challenges that play an important role.

\section{Scientific uncertainty}

Scientific uncertainty refers to restrictiveness or to the lack of available cognitive knowledge that impedes the estimation of the likelihood and magnitude of possible outcomes of undesired effects. ${ }^{17}$ Such uncertainty often results from the inability to completely or adequately reduce complexity in modelling cause-and-effect relations and refers to a lack of intelligibleness or poor quality of scientific or technical data. In the context of policymaking it is essential to acknowledge that human knowledge is always incomplete and selective and thus contingent on uncertain assumptions, assertions, and predictions; however such uncertainties can be mitigated over time. For example, in the $1950 \mathrm{~s}$, politicians and societies were unaware of the impacts of chlorofluorocarbons (CFC) on the stratospheric ozone, which caused the hole in the ozone layer.

Modelled probability distributions within a numerical relational system can only represent an approximation of the empirical relational system with which to understand and predict uncertain events. Although there is no prevailing school of thought in the literature on how to best itemise uncertainties, Silvio A. Funtowicz and Jerome R. Ravetz offer a classification of sorts of uncertainty, namely inexactness, unreliability and border to ignorance, in the context of discussions on the science-policy interface. ${ }^{18}$ This classification is instructive in distinguishing between a genuine and epistemic dimension of uncertainty, which is adjuvant deducing and applying a discursive and pragmatic policy model. ${ }^{19}$ The genuine dimension of uncertainty refers to indeterminacy resulting from a genuine stochastic relationship between cause and effect, system boundaries alluding to restricted models and a limited number of variables and parameters, and ignorance meaning the lack of knowledge about occurrence and consequences. These components have an aleatory nature, which could be alleviated to some extent by using scientific approaches but the uncertainty cannot be completely resolved. The epistemic dimension of uncertainty comprises variability in terms of vulnerability and responsiveness as well as in the effects of inference relating to systematic or random errors in modelling. These components could be offset by improving the existing knowledge and by advancing modelling tools.

If uncertainty plays a major role then the evaluation of consequences becomes fuzzy. Moreover, the validity of the end results is questionable and, for purposes of policymaking, additional information would be needed such as a subjective confidence level, potential alternative pathways of cause-and-effect relationships, ranges of reasonable estimates, loss scenarios, etc.

17 Cf. Jerzey A. Filar, and Alain Haurie (eds), Uncertainty and Environmental Decision Making (New York et al., Springer, 2010); Joseph Y. Halpern, Reasoning about Uncertainty (Cambridge: MIT Press, 2003).

18 Silvio A. Funtowicz and Jerome R. Ravetz, Uncertainty and Quality in Science for Policy (Dordrecht: Kluwer, 1990), pp. 21-5.

19 For the distinction of dimensions and components of uncertainty, see Klinke and Renn, 'A New Approach to Risk Evaluation and Management' and 'Adaptive and Integrative Governance on Risk and Uncertainty'. 


\section{Sociopolitical ambiguity}

Increased cognitive knowledge may reduce complexity and scientific uncertainty, thereby leading to more shared causal beliefs. However, increased cognitive knowledge does not necessarily reduce ambiguity because it refers to principled beliefs and worldviews. Ambiguity alludes to a state of ambivalence as actors think about, perceive, and interpret the same phenomena and their circumstances differently. ${ }^{20}$ Within sociopolitical ambiguity, an interpretative and a normative form can be distinguished. Both relate to divergent or contested perspectives on the justification, severity, wider significance, and/or spillover effects associated with a given riskrelated problem. ${ }^{21}$

Interpretative ambiguity denotes the variability of purported legitimate interpretations based on identical observations or data assessments results. Many disputes in risk-related policymaking do not refer to differences in methodology, measurements, or cause-and-effect relationships. Instead, such disputes question the implications and reasoning in terms of prevention, protection, precaution, safeguarding, sustainability, and/or human health. Moreover, in the contemporary pluralist international system, a diversity of perspectives on global risks within and between societies is generally fostered. Such diversity is based on varying principled beliefs and, in part, worldviews that lead to divergent value preferences and variations in interests. Hence, there are very few, if any universally applicable moral principles, especially when global problems are complex and uncertain. Variability in interpretation, however, is not restricted to scientific and policymaking communities where it may lead to expert dissent or even to an expert dilemma. Laypeople's perceptions often differ from expert judgments because they are also a response to qualitative characteristics such as familiarity, personal or institutional control, assignment of blame, preferences, values, etc.

This leads us to the issue of normative ambiguity, which adverts to different concepts about what can be regarded as a tolerable reference frame and meaning structure, for example, to ethics, justice, quality of life parameters, distribution of costs or risks and benefits, etc. A condition of ambiguity emerges when the problem lies in agreeing on the appropriate values, priorities, assumptions, or boundaries to be applied to the definition of possible outcomes. For instance, interpretative and normative ambiguity putatively plays a major role in the current international political debate on the security and the non-civilian use of Iran's nuclear program. Although Iran defies the International Atomic Energy Agency (IAEA) and UN Security Council resolutions and has not suspended its enrichment related activities, there is no conclusive evidence that Iran intends to produce nuclear weapons. ${ }^{22}$ Nonetheless, this contributes to the fact that countries such as USA, Israel, UK, China, Russia, Germany, and others interpret the wider meaning of the severity and potential undesirable outcome of this risk-related activity differently, which leads these states

${ }^{20}$ Cf. James G. March and Johan P. Olsen, Ambiguity and Choice in Organizations (Bergen et al., Universitetsforlaget, 1979); Nikolaos Zahariadis, Ambiguity and Choice in Public Policy: Political Decision Making in Modern Democracies (Washington: Georgetown University Press, 2003).

21 Andrew Stirling, 'Risk, Uncertainty and Precaution: Some Instrumental Implications from the Social Sciences', in Frans Berkhout, Melissa Leach, and Ian Scoones (eds), Negotiating Environmental Change. New Perspectives from Social Sciences (London: Edward Elgar, 2003), pp. 33-76.

22 See the IAEA documents on Iran, available at: $\{$ www.iaea.org/newscenter/focus/iaeairan/index.shtml $\}$ accessed August 2012. 
taking up divergent positions. Based on competing values that are embedded in varying principled beliefs and worldviews about what is acceptable and tolerable, these states draw distinctive and contradictory conclusions on what might be the right political response.

Extreme complexity and uncertainty may favour the emergence of ambiguity. However, there are also quite a few less complicated problems that can cause controversy and thus ambiguity. A crucial factor is that ambiguity may lead to social mobilisation and conflict. This becomes even more problematic when an issue not only polarises a national public discourse but also ignites conflicts at the international level.

Another example may be the irreconcilable conflict between fishing nations (for example, Japan, Norway, and Iceland), animal-protecting nations, and non-governmental organisations (NGOs). Here the underlying and recurrent questions in the context of the International Whaling Commission relate to what is tolerable versus what is intolerable as well as how and to what extent whaling might affect the protection of species.

\section{Evolution of transnational public community}

A discursive design of global risk governance with deliberative and participatory forms as the driving factors of the formation of public opinion and will across borders presupposes the 'breeding ground' of transnational public spheres and the emergence of a transnational public community. ${ }^{23} \mathrm{~A}$ transnational public sphere however, does not refer to "the frame of a bounded political community with its own territorial state $^{24}$ in which the public sphere is seen as the mediation authority between society and the political system of a nation-state. The idea of a transnational public sphere relates to common contextual frames in terms of observation, perception, action, and interdependencies, which transcend national borders. In such a contextual frame, actors perceive effects as common problems that are triggered and amplified by actions, events, and consequences beyond national boundaries. With this in mind, I review some of the scholarly literature on the transnational public sphere. ${ }^{25} \mathrm{I}$ then construct the normative configuration for the emergence of a transnational public community as the necessary condition for discourse, deliberation, and participation in global risk governance.

A transnational public sphere is a functional, issue-specific entity that is not beyond, above or detached from national and territorially differentiated public spheres, but rather emerges through the transnationalisation of discourses and the 'space for the communicative generation of public opinion' ${ }^{26}$ relating to global risk

${ }^{23}$ For a critical analysis of the role and function of global civil society - seen as public sphere - for deliberative approaches in global governance, see James Brassett and William Smith, 'Deliberation and Global Civil Society: Agency, Arena, Affect', Review of International Studies, 36:2 (2010), pp. 413-30.

24 Nancy Fraser, 'Transnationalizing the Public Sphere: On the Legitimacy and Efficacy of Public Opinion in a Post-Westphalian World', Theory, Culture \& Society, 24:4 (2007), p. 8.

25 Bohman, Democracy across Borders; Fraser, 'Transnationalizing the Public Sphere'; Thomas Risse, A Community of Europeans? Transnational Identities and Public Spheres (Ithaca: Cornell University, 2010); Jens Steffek, 'Public Accountability and the Public Sphere of International Governance', Ethics \& International Affairs, 24:1 (2010), pp. 45-68.

${ }^{26}$ Fraser, 'Transnationalizing the Public Sphere', p. 7. 
phenomena. If actors debate challenges, problems, and conflicts of common concern that arise from global risks publicly and across national borders, then a transnational public sphere becomes socially constructed. Speakers who comment or give an opinion on the collectively perceived challenges, problems, and conflicts or react to other speakers help to shape discursive arenas with a communicative production of the formation of transnational public opinion and will. Scholars argue that these actors adopt an issue-specific, transnationalised view rather than a national or otherwise partisan perspective.

Some scholars identify the potential for the emergence of transnational public spheres of various scales and scopes beyond the nation-state. For example, Thomas Risse identifies transboundary communicative spaces within the EU and a transnationalisation of public spheres emerging especially in continental Western and Southern Europe. These transnational public spheres are still fragmented and heterogeneous because of differences among member states, but they exist and similar reference frames are used by member states 'whenever European issues are debated as questions of common concern'. ${ }^{27}$ Such common concerns arising, for example, from the BSE and the current financial and currency crisis have been articulated in transnational public spheres in Europe and beyond. Moreover, the potential for transnational public spheres at the global level has been seen in contexts such as world trade policy and human rights. ${ }^{28}$ At the transboundary regional level, for instance, the transnationalisation of communicative spaces across borders and the emergence of transnational public spheres can be linked, at least in part, to a new environmental regionalism in the European Alps, the sustainable development of the Baltic Sea region, and the water governance of the Great Lakes in North America. ${ }^{29}$

I rely on an understanding of the transnational public sphere that encompasses three main conditions relating to components of a democratic system: ${ }^{30}$ (1) the availability of similar structures of meaning and reference frames relating to challenges, problems, and conflicts resulting from complexity, scientific uncertainty, and sociopolitical ambiguity; (2) speakers who treat each other as legitimate participants in the discursive arenas; and (3) actors, who, if actively engaged in discursive arenas, exchange positions, perspectives and interests by listening to each other's reasoning and trying to persuade one another on the basis of the better argument. NGOs and experts of epistemic communities play a major role as speakers in discursive arenas of transnational public spheres. They adapt and amplify common challenges, problems, and conflicts, formulate common concerns and attempt to organise the formation of

27 Risse, A Community of Europeans?, p. 6; cf. also Steffek, 'Public Accountability and the Public Sphere of International Governance'.

28 For example, Patrizia Nanz and Jens Steffek, 'Global Governance, Participation and the Public Sphere', Government and Opposition, 39:2 (2004), pp. 324-33; Jens Steffek, 'Public Accountability and the Public Sphere of International Governance'; John A. Guidry, Michael D. Kennedy, and Mayer N. Zald, 'Globalizations and Social Movements', in John A. Guidry, Michael D. Kennedy, and Mayer N. Zald (eds), Globalizations and Social Movements: Culture, Power and the Transnational Public Sphere (Ann Arbor: University of Michigan Press, 2000), pp. 1-32.

29 Cf. Jörg Balsiger, 'New Environmental Regionalism and Sustainable Development in the European Alps', Global Environmental Politics, 12:3 (2012), pp. 58-78; Kristine Kern, 'Governance for Sustainable Development in the Baltic Sea Region', Journal of Baltic Studies, 42:1 (2011), pp. 21-35; Andreas Klinke, Demokratisches Regieren jenseits des Staates: Deliberative Politik im nordamerikanischen Große Seen-Regime (Opladen: Barbara Budrich Publisher, 2006); Klinke, 'Deliberative Politik in transnationalen Räumen'; Stacy D. VanDeveer, 'Networked Baltic Environmental Cooperation', Journal of Baltic Studies, 42:1 (2011), pp. 37-55.

30 Risse, A Community of Europeans?, p. 121. 
public opinion around matters of common concern. In so doing, they challenge the political authorities of powerful international institutions on how they handle issues of global risks.

Discursive arenas in a transnational public sphere do not coercively lead to consensus; they may even evoke controversies and conflicts about disputed issues. However, active actors' engagement in discursive arenas on issues of global risks can lead to a transnational community of continuing discourse. Therefore, a transnational public sphere constitutes the space where a transnational community of discourse emerges. ${ }^{31}$ If the formation of public opinion and will in transnational discursive arenas demands transnational collective efforts and action as the best means for handling challenges, problems, and conflicts resulting from global risks, then the keystone for the creation of an action frame that furthers the institutionalisation of discursive problem solving capacity in global risk governance is created. If such an action frame is institutionalised, the transnational community of discourse segues into playing a new, more powerful and active role of a transnational public community and act as a democratic demos of the global risk governance institution. Such a transnational demos encompasses peoples across national boundaries without a determined territorial jurisdiction. ${ }^{32}$ The evolution of such a transnational public community, albeit a partial one can be observed in Canada and the USA. Here, a long-term multilevel stakeholder and public deliberation and participation system that attends to the issues of common water and environmental governance in the North American Great Lakes basin creates a transnational demos integrating peoples across Canada-USA border. ${ }^{33}$

Discourses as institutional problem solving capacity in global risk governance evolve when transnational public spheres interact with the political authorities of powerful international institutions by means of communicative processes. Partici pating in deliberative and participatory procedures, which ensure accessibility and fairness enable stakeholder representatives and individuals to convey their formation of public opinion and will into political influence. Such deliberative and participatory procedures could become regularised channels of political influence (such as elections and representation in democracies) in the absence of formal democratic institutions in international politics. ${ }^{34}$

Actors in the transnational public sphere who deliberate and participate in global risk governance institutions produce a democratically legitimate problem solving capacity without the collective identity based on a pre-political common bond that representative nation-state democracies presuppose. However, since transnational public spheres and resultant transnational public communities do not emerge out of nowhere, the actors need to be linked by at least a minimum sense of public spirit that relies on a transnational collective consciousness and intrinsic identification relating to the intersubjectivity of the reference frames.

31 Cf. Jürgen Habermas, Structural Transformation of the Public Sphere: An Inquiry into a Category of Bourgeois Society (Cambridge: Polity Press, 2008); Risse, A Community of Europeans?, pp. 107-26.

32 Cf. Bohman, Democracy across Borders.

${ }^{33}$ Klinke, Demokratisches Regieren jenseits des Staates.

34 Bohman, Democracy across Borders, p. 64. 


\section{Discursive approaches to global risk governance}

In this section, I delineate a normative approximation of postnational discourses as institutional problem solving capacity in global risk governance, which is conveyed by communicative and interactive processes of deliberation, arguing, and persuasion. Such processes rely on the power of the better argument and persuasion and can lead to a consensus in terms of the public interests and the common good of the transnational public community. My modus operandi in delineating a normative approximation is based on deductive reasoning related to theories of deliberative democracy, rational discourse, arguing, and persuasion. These theories address both ideal and pragmatic claims with regard to procedural and epistemic rationality ${ }^{35}$ and have been adopted in scholarly work in International Relations. ${ }^{36}$

This approximation of postnational discourses as institutional problem solving capacity can be seen as the development of normatively profound approaches that address pragmatic and feasible categories and criteria for how deliberative and participatory structures and processes are able to address the challenges, problems, and conflicts of global risks. For this purpose, I elaborate on three approaches of discourse foci by explaining the variation in the deliberative and participatory processing of complexity, scientific uncertainty, and sociopolitical ambiguity. The varying modalities of discourse, deliberation, and participation institutionalised in global risk governance can shed light on how to address global risk issues, how ideas of problem solving can be discussed and promoted, and how actors are involved. Discourses may be able to identify potential linkages between issues and develop partial understandings how challenges, problems, and conflicts arising from key peculiarities of global risks may be interdependent. It is, however, crucial that the issues associated with global risk challenges, problems, and conflicts are disentangled through the learning processes that develop via the distinctive discourse foci in order to tailor specific and pragmatic problem solving ideas. ${ }^{37}$ In my discussion of the three approaches, I pursue its specific idea of institutional problem solving capacity by

35 See, for example, Bohman, Public Deliberation; James Bohman, 'Survey Article: The Coming of Age of Deliberative Democracy', Journal of Political Philosophy, 6:4 (1998), pp. 400-25; James Bohman and William Rehg (eds), Deliberative Democracy. Essays on Reason and Politics (Cambridge: MIT Press, 1997); Thomas Christiano, The Constitution of Equality. Democratic Authority and its Limits (Oxford: Oxford University Press, 2008); Joshua Cohen, 'Deliberation and Democratic Legitimacy', in Alan Hamlin and Philipp Pettit (eds), The Good Polity (Oxford: Blackwell, 1989), pp. 17-34; Dryzek, Discursive Democracy; Jon Elster (ed.), Deliberative Democracy (Cambridge: Cambridge University Press, 1998); Estlund, Democratic Authority; Rainer Forst, 'The Rule of Reasons. Three Models of Deliberative Democracy', Ratio Juris, 14:4 (2001), pp. 345-78; Amy Guttman and Dennis Thompson, Democracy and Disagreement. Why Moral Conflict Cannot Be Avoided in Politics, and What Should Be Done about It (Cambridge: Belknap Press, 1996); Habermas, Between Facts and Norms; Carlos Nino, The Constitution of Deliberative Democracy (New Haven: Yale University Press, 1996); John Rawls, A Theory of Justice (Cambridge: Havard University Press, 1971).

36 See, for example, James Bohman, 'International Regimes and Democratic Governance: Political Equality and Influence in Global Institutions', International Affairs, 75:3 (1999), pp. 499-513; Bohman, Democracy across Borders; Deitelhoff, 'The Discursive Process of Legalization'; John Dryzek, 'Transnational Democracy', Journal of Political Philosophy, 7:1 (1999), pp. 30-51; Klinke, 'Democratizing Regional Environmental Governance'; Klinke, 'Deliberative Politik in transnationalen Räumen'; Risse, "Let's Argue!'”, Risse, 'Global Governance and Communicative Action'; Steffek, 'The Legitimation of International Governance'; Cornelia Ulbert and Thomas Risse, 'Deliberately Changing the Discourse: What Does Make Arguing Effective?', Acta Politica, 40 (2005), pp. 351-67.

37 Cf. Peter M. Haas and Ernst B. Haas, 'Learning to Learn: Improving International Governance', Global Governance, 1 (1995), pp. 255-85. 
taking into account the significance of the respective challenges, problems and conflicts at hand as well as the adequacy, applicability, and responsiveness of policy solutions. I attempt to ensure that issues arising from the peculiarities of global risks are adequately addressed and to safeguard the deliberative and participatory processes against asymmetric power of participants.

The three approaches are characterised by varying occurrences of bargaining and arguing. Bargaining and arguing are ideal types of communication and interaction, and do not manifest themselves as pure forms in real-world international politics. ${ }^{38}$ Rather, communication in real-world international policymaking is characterised by a mixture of the two in which either can be dominant depending on the respective situation, context, and power constellation. When bargaining is dominant, self-interested actors with the bargaining power of material and ideational resources make pragmatic demands, which are justified by credibility claims in the search of collective problem solving. As a result, they search for a compromise without changing their interests and fixed preferences. In contrast, '(a)rguing implies that actors try to challenge the validity claims inherent in any causal or normative statement and to seek a communicative consensus about their understanding of a situation as well as justifications for the principles and norms guiding their action.' ${ }^{39}$ If actors' communication is largely based on arguing, then they 'are open to be persuaded by the better argument' aiming at a collectively reasoned consensus focused on problem solving and 'the relationships of power and social hierarchies recede in[to] the background'. ${ }^{40}$ However, arguing can be strategically oriented as well. Strategic arguing relates to the use of pretended and insincere arguments and reasons for strategic purposes. ${ }^{41}$

In what follows, I distinguish between: (1) epistemological discourses that address complexity via epistemic institutions; (2) reflexive discourses that deal with scientific uncertainty by means of associational policymaking; and (3) general public discourses that handle sociopolitical ambiguity through transnational public deliberation and participation. These approaches rely mainly on the non-coercive power of arguing and persuasion. Institutionalised settings that support arguing and persuasion follow the logic of discursiveness, that means actors rely on a communicative method of reasoning and justification to produce and exchange policy solutions that are deemed socially and publicly acceptable.

However, if global risks are not associated with a high degree of complexity, uncertainty, and ambiguity, then the related problems and challenges are seen as relatively uncomplicated and linear. Such uncomplicated problems hardly require any alterations to the traditional mechanisms of international politics; governability relies upon intergovernmentalism and its institutional structures of international organisations and regimes where state actors exert the political decision-making authority. In many cases, the actors share views about an implicit deduction of strategies and policy models in order to attain collective solutions. Here, actors seek a

\footnotetext{
38 For the definition of and distinction between arguing and bargaining as well as the interplay of both, see Jon Elster, 'Arguing and Bargaining in Two Constituent Assemblies', Journal of Constitutional Law, 2:2 (2000), pp. 345-421; Katherina Holzinger, 'Verhandeln statt Argumentieren oder Verhandeln durch Argumentieren? Eine empirische Analyse auf der Basis der Sprechakttheorie', Politische Vierteljahresschrift, 42:3 (2001), pp. 414-46; Risse, "Let's Argue!"'; Risse, 'Global Governance and Communicative Action'; Ulbert and Risse, 'Deliberately Changing the Discourse'.

39 Risse, 'Global Governance and Communicative Action', p. 294.

40 Ibid.

41 Elster, 'Arguing and Bargaining in Two Constituent Assemblies'.
} 
compromise on collectively binding norms and rules, which are acceptable from the viewpoint of their cost-benefit calculations.

It is important to note that issues arising from complexity, scientific uncertainty, and sociopolitical ambiguity can hardly be considered discrete. Instead, the solutions needed to resolve the associated challenges, problems, and conflicts in global risk governance are conceived of as being interrelated and supplementary. Accordingly, the following proposed approaches of discourse, deliberation, and participation in global risk governance are an attempt to address these interrelating issues.

\section{Epistemic institutions}

Addressing the complexity of global risks assumes that actors with internationally recognised scientific expertise and competences debate controversial issues and engage in a discursive manner. Such a discourse can be seen as an epistemological discourse aggregated and expressed via transnational epistemic institutions. The focus of an epistemological discourse draws upon the process in which these actors exchange science-based facts and data, learn about cognitive and evaluative understandings, as well as clarify and define problems to be solved. Since truth seeking motivates the actors, the communication process primarily tends towards arguing. The more experts that engage in an epistemological discourse, the more likely it is that they create and substantiate a transnational community of communication that is understood in scholarly literature as an epistemic community. An epistemic community loosely connects actors with issue-specific expertise and competences seeking to collectively facilitate agreement on cognitive and normative ideas about policyrelevant problem solving. ${ }^{42}$

The global network of climate change researchers, for example, can be seen as such an epistemic community that collaboratively deals with challenges and problems of complexity as well as scientific uncertainty and, in part, sociopolitical ambiguity. ${ }^{43}$ This global network has established knowledge-based relationships, since no individual has the capacity to tackle the comprehensive cognitive problems without the cooperation of the others. The reference frames and arguments that are used by the actors resonate with their causal beliefs. For this reason, they argue over the conclusiveness and validity of cause-and-effect relations relying on available probative facts, knowledge, and logics that can be empirically verified on the basis of criteria of traceability and consistency. The objective of their deliberation is to ascertain the most cogent description and explanation of the complex phenomena in question as well as to clarify dissenting views (for example, by addressing questions related to which sociopolitical, economic, and/or environmental impacts are to be expected by specific regulatory activities). The overall goal is to establish consensual knowledge related to cause-and-effect relationships, elaborating and reasoning policy-relevant knowledge. Moreover, the aim is to collectively draw conclusions about programmatic

42 Peter M. Haas, 'Introduction: Epistemic Communities and International Policy Coordination', International Organization, 46:1 (1992), pp. 1-35; Schmidt, 'Discursive Institutionalism'.

43 Cf. Harriet Bulkeley and Peter Newell, Governing Climate Change (London and New York: Routledge, 2010); Andrew Dessler and Edward A. Parson, The Science and Politics of Global Climate Change: $A$ Guide to the Debate (Cambridge: Cambridge University Press, 2010). 
strategies and policy solutions that are collectively justified and valued based on shared causal and principled beliefs embedded in the broader context of worldviews.

Actors in epistemic communities may play an important and influential role in transnational public spheres, similar to advocacy networks in international politics, for example, in such areas as human rights, the environment, or violence against women. ${ }^{44}$ Epistemic communities generate, gather, and evaluate information and knowledge, disseminate it to governments and international organisations, and help them in formulating and advocating new national and international policies. A widely researched environmental issue is ozone depletion, and through the influence of the discourse initiated and conveyed by the transnational epistemic community, institutional changes resulted in the banning of chlorofluorocarbons. ${ }^{45}$ Due to the fact that epistemic communities and their discourses have neither political decisionmaking power nor the authority to issue rules or norms in global governance institutions, they can only gain political influence when they are institutionalised and formally constitutionalised as international research authority with consultative skills and competences. Expert advisory bodies, institutes of higher education, independent and neutral research institutes, and non-profit, impartial think tanks can be seen as epistemic institutions that provide professional expertise on complex policy issues and structures of resources in order to generate policy-relevant knowledge, as well as validate ideas of problem solving, if they are internationally recognised as points of intersection that collect and bundle the state of the art and the deliberation of the epistemic community. ${ }^{46}$ These research entities possess authority with regard to contents because they operate through a sense of credible obligation in terms of the objective and unprejudiced production of expert knowledge and systematic information that is generally accepted by the epistemic community. They can be either independent, non-profit organisations funded by national and sub-national governments or hosted by supranational organisations such as the UN or the EU. Relevant is that they are non-partisan, not politically bound by instructions of governments and not obliged to support particular interests. Ideally, the discourse within the epistemic community should elicit which entities are seen as legitimate research authorities and which NGOs can provide issue-specific expertise and competences.

The manifestation of discourses within epistemic communities through epistemic institutions can play a decisive role in the sense of a 'cognitive division of labor' ${ }^{47}$ Passing on the handling of complexity to epistemic institutions is not simply delegating a task that public actors of national governments or private actors of the transnational public community can do themselves. Instead, this process authorises an international collective actor group of recognised experts to meet the challenges, problems, and conflicts arising from complexity because they are the only actors that can generate reliable and profound scientific insights and policy-relevant knowledge in terms of cognitive and evaluative reference frames and meaning structures

44 Margaret E. Keck and Kathryn Sikkink, 'Transnational Advocacy Networks in International and Regional Politics', International Social Science Journal, 51:1 (1998), pp. 89-101.

45 Peter M. Haas, 'Banning Chlorofluorocarbons - Epistemic Community Efforts to Protect Stratospheric Ozone', International Organization, 46:1 (1992), pp. 187-224.

46 Cf. Andrew Rich, Think Tanks, Public Policy, and the Politics of Expertise (Cambridge: Cambridge University Press, 2004).

47 James Bohman, 'Democracy as Inquiry, Inquiry as Democratic: Pragmatism, Social Science, and the Cognitive Division of Labor', American Journal of Political Science, 43:2 (1999), p. 590. 
that allow for the handling of complexity. The interplay and interaction between intergovernmental decision-making structures, the epistemic community, and epistemic institutions in global risk governance arrangements can lead to a joint collaboration without thereby falling into a form a technocratic 'punditocracy' dominated by those who have epistemic advantages and who thus wield great political influence. Specifically, it is important to ensure the possibility of publicly deliberating and judging the credibility of expert authority and the legitimacy of existing social norms and procedures regulating the cooperation between public actors and experts. ${ }^{48}$ Such epistemic institutions are able to establish credentials of legitimacy because they underwrite an epistemic claim on cognitive and evaluative reference frames and meaning structures relating to the complexity of global risks. And the reference frames and meaning structures are deemed to be collectively recognised because they emanate from theoretical paradigms, empirical studies, and methodological approaches that reflect the current state of the art.

Although the epistemic status of the IPCC is disputed, ${ }^{49}$ I use it as an example to illustrate how an expert advisory system has been established as focal point of a global epistemological discourse that can be seen as an approximation of an epistemic institution. ${ }^{50}$ In the framework of the IPCC and the associated epistemic community, the multifaceted complexity of the causes and effects of climate change has been addressed and a consensus that is reasoned and widely accepted internationally of the causality between human behaviour and increased global warming has been established, even though considerable scientific uncertainty remains about the consequences. However, the implementation of the IPCC-reports is carried out by governmental actors and is therefore exposed to national and partisan interests. These national and partisan interests are sometimes influenced by powerful industrial associations that trivialise the risks of global warming.

Yet, even members of epistemic communities are also not always impartial and may not necessarily provide sincere and unprejudiced expertise. The example of political partisanship of scientists in the ozone debate and the Mediterranean regime building process demonstrates such potential bias. ${ }^{51}$ In order to overcome this possible distortion, some scholars have suggested that the credibility of the authoritative claim of an international expert advisory body in providing the cognitive basis for collective decision-making in global governance largely depends on transparency as a key element promoting discussion in the public sphere, quality management based on peer review and accountability of policy-relevant knowledge. ${ }^{52}$ In this regard, the

48 Bohman, 'International Regimes and Democratic Governance', p. 592.

49 For example, Peter Haas, 'When Does Power Listen to Truth? A Constructivist Approach to the Policy Process', Journal of European Public Policy, 11:4 (2004), pp. 569-92.

50 Cf. Bulkeley and Newell, Governing Climate Change; Dessler and Parson, The Science and Politics of Global Climate Change.

51 Peter M. Haas, 'Do Regimes Matter? Epistemic Communities and Mediterranean Pollution Control', International Organization, 43:3 (1989), pp. 377-403; Karen T. Litfin, Ozone Discourses. Science and Politics in Global Environmental Cooperation (New York: Columbia University Press, 1994).

52 Cf. Karin Bäckstrand, 'Democratizing Global Environmental Governance? Stakeholder Democracy after the World Summit on Sustainable Development', European Journal of International Relations, 12:4 (2006), pp. 467-98; Alexandru Grigorescu, 'Transparency of Intergovernmental Organizations: The Roles of Member States, International Bureaucracies and Nongovernmental Organizations', International Studies Quarterly, 51:3 (2007), pp. 625-48; Rodger A. Payne and Nayef H. Samhat, Democratizing Global Politics: Discourse Norms, International Regimes, and Political Community (Albany: State University of New York Press, 2004). 
credibility of the IPCC was critically called into question at the Copenhagen Summit and this led to demands to undertake reforms.

The epistemological discourse may also reveal that there is more hidden uncertainty and ambiguity than initially anticipated. This leads us to the question how discourses on scientific uncertainty and sociopolitical ambiguity are conveyed by means of deliberation and participation.

\section{Associational policymaking}

If global risks are predominantly characterised by high degrees of scientific uncertainty as evinced in the loss of biological diversity ${ }^{53}$ or marine fishery resources, ${ }^{54}$ then the gathering and appraisal of scientific and technical knowledge in terms of the complex nature of the global risk accomplished by epistemic institutions is only the first step towards a more elaborate discourse among collective actor groups of the state, economy, and civil society in global governance institutions. ${ }^{55}$ First and foremost, it is essential to compile the relevant and available data and information as well as the various arguments, rationales, and explanations that are based on varying causal beliefs of different expert groups in order to address cognitive dissent. Therefore, epistemic institutions do not only focus on complexity issues, they also attempt to advance assessment capabilities to reduce the potential of cognitive conflicts with respect to the genuine and epistemic scientific uncertainty. For this purpose, available information about the different types of scientific uncertainty are collected, and the unresolved potential of cognitive and evaluative conflicts are revealed. In other words, epistemic institutions generate a shared cognitive and evaluative reference system and meaning structure revealing the challenges, problems, and conflicts associated with scientific uncertainty.

However, in light of highly irreducible and irresolvable scientific uncertainty, the epistemological discourse among experts is upgraded to a form of associational policymaking in order to address the inferences and consequences resulting from the remaining scientific uncertainty. Associational policymaking fosters a group-based governance structure of transnational stakeholders and introduces an element of reflexivity in order to support an intricate process of evaluation. The actors' perceptions of and reactions to uncertainty affect the situations and contexts they are observing as well as the behaviour of actors. To meet the challenges and problems of scientific uncertainty, I turn to a reflexive discourse, meaning a process of selfreflection, self-interrogation, and self-assessment. Collective state, civil-societal, and economic actor groups scrutinise and evaluate the ability of the transnational public sphere to accept the remaining uncertainties and to tolerate the tension between the responsive actions of appropriate safeguarding and acting under insecurity. In this regard, actors encounter questions about the scope and profoundness of safety,

53 See, for example, German Advisory Council on Global Change, 'World in Transition: Conservation and Sustainable Use of the Biosphere' (London: Earthscan, 2001).

54 See, for example, Food and Agriculture Organization of the United Nations (FAO), 'Review of the State of World Marine Fishery Resources', Fisheries and Aquaculture Technical Paper 569 (Rome: FAO, 2011).

55 Cf. Klaus Dieter Wolf, 'Emerging Patterns of Global Governance: The New Interplay between the State, Business and Civil Society', in Andreas G. Scherer and Guido Palazzo (eds), Handbook of Research on Global Corporate Citizenship (Cheltenham: Edward Elgar, 2008), pp. 225-48. 
protection, and precaution. Here, perceptions of just or unjust distribution of risk and benefits are highly significant. Addressing questions and issues in terms of acceptability and tolerability that imply moral judgments are made and justified by cultural values, and ontological and ethical convictions.

The nature of scientific uncertainty, especially with regard to a lack of knowledge and the presence of unknown factors, however, means that actors in a reflexive discourse need to acknowledge that science cannot adequately describe the virtual socio-political implications resulting from scientific uncertainty. Because of this opaqueness, actors tend to use allegorical, analogous, and metaphoric language because it references something that cannot be apprehended and can only be grasped partially. Yet at the same time, the actors intuitively recognise the significance of what cannot be apprehended and conjecture as to its meaning. The actors' power to resort to associated meanings facilitates a common intuitive access that can be used to identify relevant issues and to map and delineate the challenges, problems, and conflicts relevant to the problem solving.

In the deliberative and participatory procedures that convey and aggregate a reflexive discourse stakeholder and public interest, groups are entitled to participate. Experts of epistemic institutions familiarise these collective actor groups with the cognitive and evaluative reference frames and meaning structures that relate to scientific uncertainty. Together, these actors debate and come to a convergence on whether or not, and to what extent uncertainty is reasonable for the transnational community, the necessary level of safeguarding, and the margin of safety that one is willing to invest in order to avoid undesired consequences. If the process aims at finding a right balance between too little and too much precaution, then the reflexive discourse focus attains institutional problem solving capacity. Such a balancing process entails assessing trade-offs between the competing extremes of over- and under-protection, and searching for a pareto-optimal equilibrium in the degree of regulation.

Transnational associational policymaking fosters the devolution of the evaluative function to stakeholders (representing governmental and economic interests) and public interest groups (representing the civil-societal interests of the transnational community). The advantage is that the latter groups have insights and experiences gleaned from social life, which can lead to a commonsense handling of uncertainty as well as to a deliberation of generalised interests. This creates a socially robust problem solving capacity on how to manage the effects of uncertainty. Associational policymaking therefore evaluates to what extent preventive, adaptive, and mitigative strategies and measures (for example, containment of application, safety margins, extending retention, etc.) are deemed socially acceptable by referring to the public use of reason. The classical intergovernmental power diminishes and the responsibility to generate problem solving capacity is transferred to non-hierarchical and dialogue-oriented processes among stakeholder and public interest groups who have equal rights. A central function of nation-states is to facilitate adequate deliberation and participation in organisational structures of global governance and the protection of the rights of the participating groups. The result is viable governance institutions with institutional problem solving capacity in terms of uncertainty conducted by governmental, civil-societal, and economic stakeholder groups, in which the role of the nation-states has changed. State actors need to adapt to a new role as copolicymakers and as guardians of the deliberation and participation processes. 
The particular challenge for associational policymaking in global governance arrangements is for different actor groups, with diverse logics of action, to produce collectively acceptable solutions. Policymakers are bound to their political institution and constituents, and their action is influenced by political decision-making structures. Economic actors are influenced by market mechanisms, and their action is focused on creating basic conditions beneficial for production or services. Civil society stakeholders are marked by ideational commonalities and the willingness of their members to cooperate. The actions of their representatives are guided by the solidarity of the members and majority decisions. Scientists are driven by the rational search for the cognitive truth as they refer to existing facts, factual knowledge, and logics, which can be scientifically verified. Except for scientists, the participating actors in associational policymaking are representatives of organisations, that means they are not absolutely free in their collaborative behaviour because they need the endorsement of their own organisations. Hence, it is necessary that the actors achieve consensus both at the level of the global governance institution and within their organisations.

It is possible that associational policymaking can become uncoupled from traditional international political organisations, constitutional requirements, and classic systems of societies and politics. This policymaking form is self-organised as a network partnership structure, in which arguing and persuasion, and less bargaining, characterise the interaction and collaboration. ${ }^{56}$ The aggregation of the reflexive discourse, and thus the production of a collective problem solving capacity, is feasible through participatory-deliberative procedures such as negotiated rule-making, mediation, or round-table discussions. These have often proven to be valuable means for the involvement of stakeholder and public interest groups in domestic politics. ${ }^{57}$ The properties and conditions of such procedures facilitate argumentative rationality through communication and deliberation based on arguing and non-manipulative persuasion aimed at mutual understanding and learning as well as seeking a collectively reasoned consensus with respect to acceptable solutions.

The Stewardship Council FSC serves as an example of how an approach to associational policymaking can be implemented in a transnational governance institution run by non-state actors. ${ }^{58}$ The FSC is one of the oldest and most institutionalised certification schemes with arenas for reflexive discourse, policymaking by various stakeholder and public interest groups (for example, environmental NGOs, the timber industry, state-run forest management and organisations of indigenous people), and power-sharing in stakeholder bodies. ${ }^{59}$ The process of forming rules and norms for certification and labelling includes dialogue- and consensus-oriented procedures where arguing predominates. However, the decision-making structure itself is a majority-democratic structure consisting of three chambers (representing economic,

56 Risse, "'Let's Argue!"'; Risse, 'Global Governance and Communicative Action'.

57 See, for example, Thomas C. Beierle and Jerry Cayford, Democracy in Practice. Public Participation in Environmental Decisions (Washington: Resources for the Future, 2002); Ortwin Renn, Thomas Webler, and Peter M. Wiedemann (eds), Fairness and Competence in Citizen Participation (Dordrecht: Kluwer, 1995).

58 Cf. Klaus Dingwerth, 'North-South Parity in Global Governance: The Affirmative Procedures of the Forest Stewardship Council', Global Governance, 14:1 (2008), pp. 53-71; Sally Eden and Christopher Bear, 'Third-sector Global Environmental Governance, Space and Science: Comparing Fishery and Forestry Certification', Journal of Environmental Policy \& Planning, 12:1 (2010), pp. 83-106.

59 Sander Chan and Philipp Pattberg, 'Private Rule-Making and the Politics of Accountability: Analyzing Global Forest Governance', Global Environmental Politics, 8:3 (2008), pp. 103-21. 
environmental, and social interests) with voting power. Collectively binding decisions need the consent of all three of these chambers. The associational policymaking in the FSC promotes a certification scheme as a policy solution that meets the challenges and problems of scientific uncertainty. The FSC, however, is rather restricted in the area of problem solving because the broader debate of the trade-offs between the protection and use of forests worldwide does not take place. The FSC also lacks an epistemic institution that addresses complexity issues on the role of forests as a renewable natural resource, as a sink or as an emission source of $\mathrm{CO}_{2}$.

The feasibility of associational policymaking procedures promoting arguing among stakeholder and interest groups implies specific critical problems that differ in three ways. First, associational policymaking needs to address the challenges and issues of inclusion and exclusion, representation, affiliation with a transnational public sphere, the appropriate procedures for stakeholder and interest group participation and deliberation, as well as the role of gate-keeping. Which stakeholders are entitled to participate? Who determines who is a relevant stakeholder in the transnational community? Whose interests, principled beliefs, and worldviews do the stakeholders represent? Should all stakeholders be given equal access to political influence? How can democratic claims such as equal opportunities, fair representation, and accountability be validated in participatory procedures? What are the appropriate procedures to promote arguing? The role and relevance of stakeholders and interest groups is contested. Some scholars criticise the lack of accountability and legitimacy as well as the disparities in the representation of stakeholders from different geographical regions. ${ }^{60}$ Yet others view stakeholder participation as an innovative form of a new governance institution that could overcome obstacles of intergovernmental cooperation by bringing together the key actors of governments, civil society, and economy. ${ }^{61}$ However, they can hardly provide new responses to or ideas regarding the above questions.

Second, associational policymaking refers to how stakeholders and interest groups can exert political influence by means of arguing and persuasion. In the first place, the properties and conditions of such procedures should facilitate publicly acceptable arguments and the justification of interests by the participating actors, and reward them by doing so, and focus on what can be argued reciprocally and generally in terms of solutions that persuade others. ${ }^{62}$ The representation of stakeholders and public interest groups in associational policymaking raises the critical problem of accountability. To whom are the representatives accountable? Should they be committed to the general interests of the common good of the transnational community and the persuasive power of the better argument, or should they only represent the interests of their constituency? ${ }^{63}$ The former alternative would promote arguing while the latter would rather tend towards bargaining. None of the critical aspects can be entirely resolved in terms of associational policymaking, since one alternative places too much responsibility on the representatives while the other strongly depends on the feedback to the constituency.

60 Dingwerth, 'North-South Parity in Global Governance'; Donald H. Schepers, 'Challenges to Legitimacy at the Forest Stewardship Council', Journal of Business Ethics, 92 (2010), pp. 279-90.

61 Bäckstrand, 'Democratizing Global Environmental Governance?'; Charlotte Streck, 'New Partnerships in Global Environmental Policy', Journal of Environment and Development, 13:3 (2004), pp. 295-322; Wolf, 'Emerging Patterns of Global Governance'.

62 Forst, 'The Rule of Reasons'.

63 Cf. Guttman and Thompson, Democracy and Disagreement, p. 128. 
Third, discursive coalitions of stakeholders and public interest groups may be unlikely to develop or even fail to generate associational policymaking if actors do not share common cognitive and evaluative reference systems and meaning structures because of an underlying expert/lay divide or moral disagreement. ${ }^{64}$ The nature of scientific uncertainty implies that experts have no clear and complete understanding of phenomena, issues, and consequences relating to global risks. Furthermore, the heterogeneity within epistemic communities and transnational public spheres means that dissent might prevail among experts as well as differences between the perceptions and conclusions of experts and laypeople.

Moral disagreements arise because collective actor groups in pluralistic societies, and especially in transnational public spheres, may not share the same ethical principles, norms, and values because they embrace different beliefs and world views from which they draw on judgments about what are the right or wrong strategies to cope with uncertainty. Michael Thompson and Steve Rayner explain that the discourses of global climate change include both the divide between the perceptions and deductions of experts and laypeople about what should be done, as well as moral disagreements arising from discrepancies in ethical and cultural value targets. ${ }^{65}$

An example of another incommensurate understanding between experts and laypeople is the issue of nuclear energy. ${ }^{66}$ Scientific and public acceptance of nuclear energy decreased significantly in the 1970s and 1980s because of new risk assessments, which led to an expert dilemma and expert/lay cleavages. As a result, the risks of an accident, a plane crashing into a nuclear energy facility, and terrorist attacks have been evaluated differently by opponents of nuclear energy who have been bolstered by commensurate scientific expertise than they have been by official nuclear safety agencies. Although nuclear safety agencies provided a quantitative and thus an alleged objective risk evaluation, the public was not impressed by the detailed assessment and the low probability of the occurrence of accidents in terms of numerical values, and was not open to compromise. A specific scientific understanding that was driven by natural science and technology generated a collective understanding that was doomed to fail because the public referred to patterns other than engineerlike thinking.

Both, the expert/lay distinction and moral disagreement are marked by interpretative and normative ambiguity as well, which leads us to the final discourse approach.

\section{Transnational public deliberation and participation}

A broad general public discourse within the transnational community can tackle the challenges, problems, and conflicts arising from sociopolitical ambiguity. Such a discourse benefits from transnational public deliberative and participatory procedures, in which individuals of the peoples in the transnational public sphere are

${ }^{64}$ Cf. Michael Thompson and Steve Rayner, 'Risk and Governance Part I: The Discourses on Climate Change', Government and Opposition, 33:2 (1998), pp. 139-66; Karin Bäckstrand, 'Civic Science for Sustainability: Reframing the Role of Experts, Policy-Makers and Citizens in Environmental Governance', Global Environmental Politics, 3:4 (2003).

65 Thompson and Rayner, 'Risk and Governance Part I'.

66 Armin Grunwald, Technikfolgenabschätzung - eine Einführung (Berlin: Edition Sigma, 2010), p. 155. 
entitled to participate across borders and who thus are given co-policymaking authority in global risk governance institutions. The formation of opinion and will of a transnational general public discourse can be institutionalised by a 'macro-political uptake' 67 of deliberative and participatory procedures such as citizen panels or juries, voluntary public advisory groups, and consensus conferences. ${ }^{68}$ These procedures evince a micro-cosmopolitan public deliberation and participation by involving transnational mini-publics of lay people and nonpartisan, unorganised individuals of the transnational public community. Such institutionalised procedures constitute the intersubjective framework in which the transnational discourse on ambiguity achieves normative importance for policymaking through global governance. In particular, the deliberative and participatory character of the procedures serves to ensure at least two normative requirements for the conveyance of a transnational general public discourse: (1) open and fair opportunities for anyone who wishes to actively participate; and (2) the possibility of having political influence by means of something like 'the effective use of free public reason'. ${ }^{69}$ If the procedures allow individuals fair opportunity to influence the problem solving search, then democratic claims such as equality, freedom, publicity, control, and authentic interest mediation in global governance institutions are made operational in some way. ${ }^{70}$

Such procedures promote arguing and persuasion as modes of social interaction and communication and decrease the likelihood of bargaining and strategic behaviour. The public character of the procedures prompt the participating actors to impose norms of reciprocity on their behaviour, to give and take reasons that enhance the quality of justification, to aspire to a kind of political reasoning that is mutually justifiable, to cast proposals in relation to the common good, to consider the future consequences of decisions, and to collectively search for solutions that can be accepted by the transnational community. ${ }^{71}$

Public deliberation and participation procedures create a forum to exchange competing arguments and interpretations and in which beliefs and values are openly discussed. The chance to resolve conflicting cognitive, evaluative, and normative expectations lies in the process of firstly identifying reliable consensual cognitive knowledge. Moreover, it is important to discuss and define collective norms and rules that are ethically acceptable and just from a global perspective, and fair when common resources need to be used and institutional means need to be activated for achieving common good solutions. ${ }^{72}$ Participants are poised to scrutinise and change

67 Robert E. Goodin and John S. Dryzek, 'Deliberative Impacts: The Macro-Political Uptake of MiniPublics', Politics \& Society, 34:2 (2006), pp. 219-44.

68 Scholarly work indicates that these procedures give participants equal rights and that they convey argumentative rationality, see, for example, Baber and Bartlett, Global Democracy and Sustainable Jurisprudence; Beierle and Cayford, Democracy in Practice; Goodin and Dryzek, 'Deliberative Impacts'; National Research Council, Public Participation in Environmental Assessment and Decision Making (Washington: The National Academies Press, 2008); Renn, Webler, and Wiedemann, Fairness and Competence in Citizen Participation.

69 Bohman, 'International Regimes and Democratic Governance', p. 503.

70 Ibid.; Jack Knight and James Johnson, 'What Sort of Equality Does Deliberative Democracy Require?', in James Bohman and William Rehg (eds), Deliberative Democracy. Essays on Reason and Politics (Cambridge: MIT Press, 1997), pp. 279-319.

71 Cf. Bohman, 'International Regimes and Democratic Governance'; Cohen, 'Deliberation and Democratic Legitimacy'; Forst, 'The Rule of Reasons'; Guttman and Thompson, Democracy and Disagreement.

72 For discussions on global ethics and global justice, see Kimberly Hutchings, Global Ethics. An Introduction (Cambridge: Polity Press, 2010); Kimberly Hutchings, 'Global Justice', in Colin Hay (ed.), New Directions in Political Science: Responding to the Challenges of an Interdependent World (Houndmills: Palgrave Macmillan, 2010). 
their preferences, belief systems, and even their identities. Individuals cooperate in cases of cognitive, evaluative, and normative conflicts if the procedures are fair and thus they have reasonable expectations when it comes to persuading others of the cogency of their reasons. ${ }^{73}$ If deliberative and participatory procedures result in the formation of public opinion and will of a transnational general public, then it can have collectivising and civilising effects on the participants because they are hardly able to defend and justify self-serving interests and strategic behaviour in such a context. ${ }^{74}$ The participants are induced to base their interest claims on the common good of the transnational community, which, in turn, represents a reference frame and meaning structure that is collectively accepted.

Problem solving capacity through transnational public deliberation and participation is thus predicated on the legitimacy of the deliberative and participatory features of the procedures and the idea that these procedures can generate acceptable rules and norms as solutions that address ambiguity. The more actors recognise the procedures as an adequate action frame to produce publicly and socially acceptable norms and rules, the more actors of the transnational community comply voluntarily with the outcome of a transnational public deliberation and participation process. This compliance, in turn, strengthens the binding forces, social solidarity and civilising effects within the transnational community. The public acceptability of an institutional problem solving capacity through transnational public deliberation and participation then relates to three factors: (1) the actors share beliefs that the procedures are the best ways to generate adequate norms and rules of problem solving when they are confronted with ambiguity; (2) the procedures provide fair access to influence the political decision-making; and (3) the norms and rules produced to resolve the problem are morally good and right.

The Great Lakes regime is an example of how a transnational general public discourse has been, at least in part, conveyed through public deliberation and participation across national borders. ${ }^{75}$ The International Joint Commission established an expert advisory system that made the necessary cognitive knowledge available as well as organised and facilitated a multilevel, transnational public deliberation and participation system. In this system, cognitive, evaluative, and normative conflict potentials were addressed and often resolved by seeking a reasoned consensus that served as a basis for the Commission's decision-making. Different procedures of public deliberation and participation were institutionalised at different politicalinstitutional levels: public hearings that ensured fair access for all citizens at the binational level, but only declamatory and sequential assertion of statements with hardly any argumentative exchange were permitted; publicly accessible workshops and meetings in which argumentative rationality and collective preference formation were of high quality; and public advisory committees at the regional and local levels where arguing and collective preference formation mostly prevailed. A major weakness, however, was that the results of these procedures were aggregated by the expert advisory bodies and not by a separate deliberative mechanism. How and to what

73 Cf. Bohman, 'Survey Article', p. 407.

${ }^{74}$ Cf. Elster, 'Deliberation and Constitution Making'; Elster, 'Arguing and Bargaining in Two Constituent Assemblies'.

75 Klinke, Demokratisches Regieren jenseits des Staates; Klinke, 'Deliberative Politik in transnationalen Räumen'. 
extent the public participation system can exert real policymaking authority still remains relatively unclear.

Despite its benefits, institutional problem solving capacity through transnational public deliberation and participation in global risk governance poses major challenges that need to be addressed. Public deliberation and participation procedures such as citizen panels or juries, voluntary public advisory groups or consensus conferences are small groups of individuals who deliberate together. The selection of individuals who will participate in such procedures and who have policymaking authority in the area of ambiguity again relates to disputed issues of representativeness, inclusiveness, and exclusiveness. Who is entitled to participate? Whose interests are represented? How can we involve those whose interests are not represented? Which criteria or rules of inclusion are justifiable and legitimate?

First of all, such deliberative and participatory procedures can claim to be representative of the transnational community to some extent, but do not draw upon statistical representativeness or electoral representation. ${ }^{76}$ Rather, such procedures ensure that social diversity, plurality of interpretations and the underlying beliefs and values of the transnational public community are adequately represented through the direct involvement of individuals. This claim of representativeness only reflects an extraction of social characteristics and viewpoints of the transnational community and is not a proportional representation or a selection based on partisanship. The participating individuals are also not accountable to the transnational community in the same way as elected representatives are.

Second, the inclusion rules of public deliberation and participation can rely on self-selection and random sampling. Self-selection is the method most often used for public hearings and notice-and-comment rule making where everyone who wants can participate. While this method provides equal opportunity for all actors it favours organised interests that have enough transboundary resources to monitor opportunities for political influence and to mobilise members of interest groups. Observing and realising the opportunity to have political influence in a transnational public sphere is particularly difficult for individuals who are not part of organised interests. Furthermore, the participants' assertions of their interests and preferences in procedures where anyone can participate are mostly declamatory and sequential. As a result, the logic of discursiveness in terms of the give and take of reasons and argumentative rationality aimed at collective preference formation is considerably impeded.

Although some scholars of deliberative democracy claim that its legitimacy is based on the deliberation of all, ${ }^{77}$ this 'becomes implausible as soon as the appropriate definition of what we mean by "all" is called into question"78 in the context of the blurred borders of a transnational public sphere. The inclusion of all is an ideal claim and transnational public deliberation and participation does not need

76 Cf. Goodin and Dryzek, 'Deliberative Impacts', p. 221.

77 Seyla Benhabib, 'Toward a Deliberative Model of Democratic Legitimacy', in Seyla Benhabib (ed.), Democracy and Difference. Contesting Boundaries of the Political (Princeton: Princeton University Press, 1996), p. 68; Bernard Manin, 'On Legitimacy and Political Deliberation', Political Theory, 15:3 (1987), p. 352 .

78 Claus Offe and Ulrich K. Preuss, 'Democratic Institutions and Moral Ressources', in David Held (ed.), Political Theory Today (Cambridge: Polity Press, 1991), p. 166. 
to depend on every decision on the handling of ambiguity being the product of deliberation of every member of the transnational community. ${ }^{79}$ Random sampling based on specific criteria considered relevant for the decision (for example, location, vulnerability, age, race, social levels), is most often applied to ensure that the selected group is representative. A shortcoming of random selection is that a small group may not fairly represent the range of underlying norms and values with respect to ambiguity. To overcome some obstacles of representativeness and inclusiveness, I propose that the implementation of fair access to transnational public deliberation and participation procedures is carried out via registration, through which individuals signal their interest in participating. Random sampling of individuals on the registration list then determines who is selected as a participant.

\section{Conclusion}

In this article, I tried to dispel, normatively speaking, the ostensible incapability of global governance institutions to handle global risks. I have expounded on peculiar features of global risks, which are itemised and classified as complexity, scientific uncertainty, and sociopolitical ambiguity. Thereupon, I argued that there is a causal link between these features and postnational discourses, that means that discourses conveyed by varying deliberative and participatory forms create institutional problem solving capacity when facing global risks. In referring to three particular discourse foci, I made a stab at justifying how epistemic institutions, associational policymaking and general public deliberation and participation meet the challenges, problems, and conflicts arising from complexity, scientific uncertainty, and sociopolitical ambiguity. Anyone who attempts to categorise global risk peculiarities and discourses in the manner described in this article runs the risk of normative-analytical quicksand. And my attempt to extricate writer and reader from these difficulties by being logical, coherent, and plausible may mean that I was sucked even deeper into the mire. The problem of categorisation is knotty because I am supposed to eschew overlapping and redundancy as well as highlight interplay, coordination, and interdependence. To distinguish approaches of discourse, deliberation, and participation is thus to place them in a special category of fragility because they are distinctive yet intertwined and interacting. In so doing, I stressed the variation in the explanatory power of discourse, theorised in discursive institutionalism, as new approach that produces institutional problem solving capacity in global risk governance. This article contributes to the debate about a further systematisation and refinement of the explanatory power of discourse in the light of new institutionalism.

The discussion of the conditions, adequacy, and functionality of the epistemological, reflexive, and general public discourse has shown that adequate conveyance and aggregation enhance the problem solving capacity in relation to problems, challenges, and conflicts resulting from global risks. Moreover, this problem solving capacity can contribute to democratising global governance institutions because it can strengthen the role and importance of non-state actors in international relations by shifting policymaking authority. If global risks reveal key peculiarities, then varying problems, challenges, and conflicts arise and the discursive global governance

79 Cf. Bohman, 'Survey Article', p. 418. 
arrangement needs to change the deliberative and participatory approach in order for it to adapt to the issue. In sum, the following elements help to improve its credentials in terms of legitimacy and effectiveness of global risk governance institutions: (1) arranging discursive settings in which deliberation, arguing, and persuasion are promoted; (2) making use of epistemic communities and impartial expert advisory bodies to resolve cognitive conflicts; and (3) incorporating elaborate procedures so that stakeholders and the public can participate in handling evaluative and normative conflicts.

I do not claim that the proposed types of discourses can ever be empirically implemented in pure form in real-world international politics; they rely on the concepts of rational discourse, deliberation, arguing, and persuasion that are normative theories based on idealisations. 'Uneven power distribution, a lack of institutional safeguards, and the fragmented nature of the international system add up to a significant obstacle to discourse and persuasion. ${ }^{80}$ Yet even the approximation of the discursive settings within global risk governance institutions can have effects that enhance the quality of institutional problem solving capacity of issues of complexity, uncertainty, and ambiguity, and thus a global capability to more effectively tackle global risks.

However, it is important to face up the difficulties and obstacles regarding the institutionalisation and feasibility of the proposed discursive settings in global governance institutions. I like to pay attention to two kinds of crucial questions and problems that cannot be answered or resolved conclusively or generalised about from the theoretical-conceptual perspective of a normative approximation.

First, the proposed discourses rely on the involvement and active participation of collective and individual non-state actors in transnational deliberative and participatory processes. This claim has a procedural dimension to it concerning questions and problems of inclusion or exclusion, the gate-keeping role, representativeness, and adequate forms of direct participation. Which non-state collective actor groups and/ or individuals of the transnational public community are selected for participation? How are they selected? Which interests and preferences of the transnational community do stakeholders and interest groups represent? Who does decide on the rules governing the representation of interests? Which participatory and deliberative procedures are most adequate? Answers to these questions are contested and controversially discussed in policy and academic literature alike. ${ }^{81}$

Second, the deliberation and participation in discursive settings presuppose procedural properties and conditions that facilitate arguing and persuasion on the one hand and hamper bargaining and strategic behaviour on the other hand. Here my argument focuses on a substantial claim that policymaking authority through discourse ensures that the participating actors will assert publicly acceptable reasons and justifications for their interests and preferences. Such public reasoning presupposes individual capability, willingness, and reliance in terms of deliberative skills and competences. Hence the effective use of free public reason depends on

80 Deitelhoff, 'The Discursive Process of Legalization', p. 61.

81 The extensive literature on those questions and issues cannot be recognised here, see, for example, Archon Fung, 'Survey Article: Recipes for Public Spheres: Eight Institutional Design Choices and Their Consequences', Journal of Political Philosophy, 11:3 (2003), pp. 338-67; Goodin and Dryzek, 'Deliberative Impacts'. 
actors " "translat[ing]" their claims into a mutually justifiable language'82 and 'distinguish[ing] good and convincing from bad and unpersuasive reasons' ${ }^{83}$ The more the actors argue in favour of the transnational community's common good, the more likely it is that they can resolve cognitive, evaluative, and normative conflicts and produce institutional problem solving capacity. Yet the reference frame of the common good needs a discursive 'formation of a public conception of the common good' 84 with regard to the transnational public community. Here, the question of inclusion comes up again, 'whose good ought to be taken into account' and 'what, substantively speaking, is the common good' 85 of the transnational community. If the relevant framework of action is politically, socially, and/or territorially specified, then the reference frame of the common good can gain validity, accountability, and credibility. The substantial dimension of the common good can include prosperity, full employment, education, health, peace, social, military and civil security, sustainable use of natural resources, and/or sustainable growth. Neither a hierarchy nor an accounting of these units is possible. However, it is possible to resort to the category of justice because it can provide an ultimate justification to obviate arbitrary judgments. ${ }^{86}$ Justice, in turn, is a relational term and has to be defined, for example, as compensatory, distributional, intergenerational, or procedural justice within the discourse.

The potential to enhance democratic legitimacy and the possibility of making good decisions about socially acceptable norms and rules that are publicly regarded as valid in the transnational public community in order to tackle problems, challenges, and conflicts associated with global risks is a long-term effort advanced by epistemological, reflexive, and general public discourse that promotes arguing and persuasion. Such discourses invigorate the unifying and society-building forces in transnational public communities as a democratic demos in which the traditional state power is usually lacking and the boundaries between domestic and international space is blurred. In the meaningful sense of a democratic polity in a transnational space, the institutionalisation of discursive global governance arrangements can lead to an international civilisation process by giving peoples across borders an opportunity to exert policymaking authority on the handling of global risks through: (1) reshaped existing global governance institutions; and (2) new and innovative global governance institutions. First, existing global governance institutions need to become institutionalised focal points and step into new, active roles as facilitators so that discourses about the handling of complexity, uncertainty, and ambiguity are conveyed by adequate deliberative and participatory procedures. Second, new global risk governance arrangements need to be institutionalised with adequate deliberative and participatory procedures as deliberative-democratic polity. These procedures are essentially different in their design, architecture, and constitutionalisation than the intergovernmental organisations and regimes that traditionally control the international system. Thus, the transnational public sphere and its further development

82 Forst, 'The Rule of Reasons', p. 362.

83 James Bohman, 'Deliberative Democracy and Effective Social Freedom: Capabilities, Resources and Opportunities', in James Bohman and William Rehg (eds), Deliberative Democracy. Essays on Reason and Politics (Cambridge: MIT Press, 1997), pp. 337-8.

84 Cohen, 'Deliberation and Democratic Legitimacy', p. 19.

85 Robert A. Dahl, Democracy and Its Critics (New Haven and London: Yale University Press, 1989), p. 306.

86 Christiano, The Constitution of Equality. 
into a transnational public community can act as the democratic constituency in world politics through which discursive global risk governance institutions are legitimised as they are constructed and reconstructed via arguing, deliberation, and persuasion in the absence of formal mechanisms such as elections in a representativedemocratic polity. The manifestation of epistemological, reflexive, and general public discourses in transnational public communities by means of varying forms of deliberation and participation can be seen as processes that develop constitutions for global risk governance institutions and carried out by peoples across borders.

A comprehensive empirical analysis of the effects of the design of the discursive settings in global governance institutions is beyond the scope of this article. However, such an analysis is an essential task for future scholarship. Any such analysis should refine the essential categories and criteria of the three discursive settings and make them operational. One key implication of my normative-analytical conception for future research is that any assessments of problem solving capacity should be conducted in an empirical manner, informed by best available policy and governance analysis as well as discourse analysis. Such an investigation would constitute a comparative analysis that relates to discursive institutionalism and would be informed by a normative-analytical design such as the one that I have put forward. 